\title{
THE INFLUENCE OF THE EXHAUST SYSTEM LEAK ON THE OPERATING PARAMETERS OF A TURBOCHARGED SPARK IGNITION ENGINE
}

Turbocharging of an internal combustion engine is the most common technique to improve an engines' performance. In present it is not hard to meet vehicles on the road with turbocharged SI engines, which have a high mileage, and because of this fact there is a high risk of exhaust systems leak. This might have its influence not only on the emissions, but also on the vehicles performance. Thereby this dissertation shows the comparative analysis of the influence of exhaust system leak in the catalyzer input on the exhaust gasses composition in the catalyzer output and the operation parameters of an turbocharged SI engine. During the research some parameters were recorded and compared, e. g.: the engines power and torque, the injectors opening time, the oxygen sensors voltage signals in the input and in the output of the catalyzer, the concentration of harmful gasses in the exhaust tailpipe. The research was conducted with the use of a single roller MAHA MSR 500 chassis dynamometer. A series of torque measurements was performed. Under these measurements a simulation of the exhaust system leakage of a turbocharged SI passenger car engine was made. As a result three variations of the wideband oxygen sensor acting were reached. The wideband sensor is mounted between the turbocharger unit and the input of the catalyzer. In the test the influence of the leakage on the injector's opening time and the composition of harmful exhaust substances were pointed.

\section{INTRODUCTION}

Nowadays, turbocharging is the most popular way to improve performance and efficiency of internal combustion engines. Initially it was mostly used in compression ignition engines, however more and more stringent emission standards (EURO, EPA) forced the use of turbocharging in the spark ignition engines. Currently, it is not uncommon to encounter turbocharged SI engine vehicles with high mileage, and because of this fact, they have a high risk of malfunctions occurring, e. g. exhaust system leak. Such breakdown might have an influence on emissions, but also on the vehicle's engine performance and reliability.

This dissertation includes the analysis of selected indicators of a passenger vehicle turbocharged spark ignition engine operation. During the research select parameters were recorded and compared, e. g.: the engine power and torque, the injector opening time, the oxygen sensor voltage signals in the input and in the output of the catalyst.

The research was conducted using a single roller MAHA MSR 500 chassis dynamometer. A series of engine torque measurements was performed. Basing on the experiment, a simulation of exhaust system leakage of a turbocharged SI passenger car engine was performed. As a result, three variations of the wideband oxygen sensor operation were reached. The wideband sensor is mounted between the turbocharger unit and the input of the catalyzer.

\section{THE EXHAUST SYSTEM OF A TURBOCHARGED SI ENGINE}

Compared to a naturally aspirated (N/A) engine, the exhaust system of a turbocharged (TC) engine is similar in some aspects. Both of them should evacuate the exhaust gasses out of the vehicle's body area (e. g. by the exhaust pipe of appropriate length), reduce the noise made by the burning gasses leaving the combustion chamber of the engine with supersonic velocity (by silencers) and also lower the toxicity of the gasses (by catalytic converters, diesel/gasoline particulate filters). Both systems use oxygen sensors to provide the possibility of measuring the concentration of oxygen left in the exhaust gasses and therefore calculate the air - fuel ratio (AFR) to obtain the mixture optimum for each operating conditions. Those sensors are also commonly used to check if the catalytic converters are working properly.

There are also some differences in the exhaust system tasks. A $N / A$ engine's exhaust should support the process of the combustion chamber load exchange. In other words it should help the burned gasses to leave the combustion chamber. A TC engine's exhaust system should provide the possibility of using the maximum of the kinetic energy of the gasses leaving the combustion chamber to drive the turbocharger's turbine wheel and after that let the gasses to leave the exhaust system as soon as possible [1]. This lowers the inertia of the intake air pressure regulation system and accelerates the reaction of the engine to the signal coming from the acceleration pedal [1]. This aspect is mostly important in first seconds of the intense acceleration process, while minimization of the lack of driving force is needed [2].

The evacuation of burned gasses out of a N/A engine takes place with a pressure that's higher than the atmospheric pressure. In a turbocharged engine the pressure of the exhaust gasses before the turbine wheel is higher than the atmospheric one too, but it is also higher than in a N/A engine because of the resistance of the turbine wheel blades. High exhaust gasses pressure hampers the load exchange.

\section{TEST FACILITY}

The research was conducted using a Volkswagen Passat passenger car. The drivetrain of the vehicle comprises of a turbo- 
charged SI engine (table 1) and a manual gearbox. A scheme of the tested vehicle's exhaust system is shown in figure 1.

The turbocharger (model KKK K03) rotation speed and the intake air pressure are regulated with the use of a waste gate. The mileage read off of the odometer right before the start of the test amounted to about $410000 \mathrm{~km}$. This is the real mileage of the vehicle, and its operating and maintenance conditions made it possible for the engine to not undergo a main repair or replacement during the whole operation time of the vehicle.

Tab. 1. The tested VW Passat engine data

\begin{tabular}{|l|l|l|l|l|l|}
\hline Engine & $\begin{array}{c}\text { Capacity, } \\
\mathbf{c m}^{3}\end{array}$ & $\begin{array}{c}\text { Engine } \\
\text { built } \\
\text { type }\end{array}$ & $\begin{array}{c}\text { Number of cylin- } \\
\text { ders / valves / } \\
\text { valve gear }\end{array}$ & $\begin{array}{c}\text { Maximal } \\
\text { power } \\
\text { PS (kW) / RPM }\end{array}$ & $\begin{array}{c}\text { Maximal } \\
\text { torque, } \\
\text { Nm / RPM }\end{array}$ \\
\hline $1.8 \mathrm{~T}$ & 1781 & $\mathrm{R} 4$ & $4 / 5 / \mathrm{DOHC}$ & $\begin{array}{l}150(110) \\
5700\end{array}$ & $210 / 1750-4600$ \\
\hline
\end{tabular}

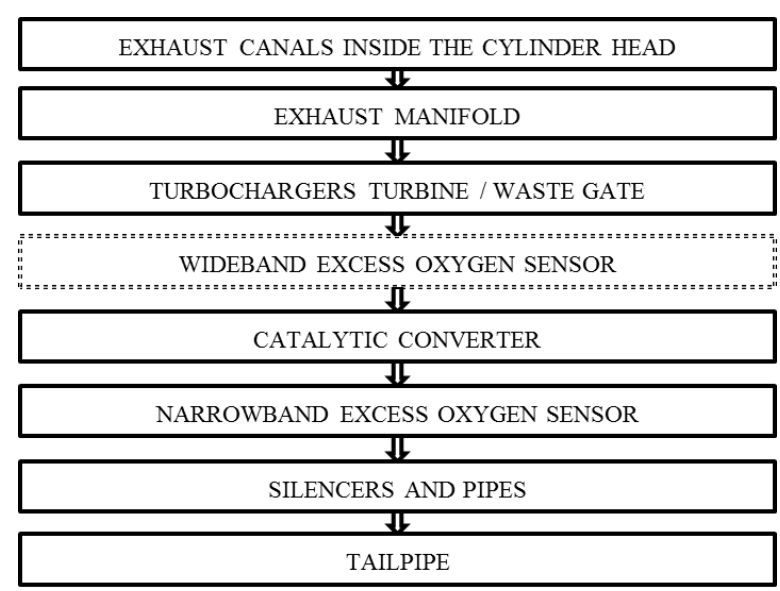

Fig. 1. Scheme of the tested vehicle's exhaust system; the element marked with dotted line is the part of the scheme, where the leakage was simulated

MAHA MSR 500 single roller chassis dynamometer and MAHA MGT5 4-gas tester were also used in the research. After the tested vehicle was fixed on the dynamometer and its engine reached a stable operating temperature the engine torque measurement was conducted. In the next steps, the exhaust system was modified twice and new torque measurements were performed each time. Data regarding for example: concentrations of toxic substances in exhaust gasses, injector opening times and intake air mass flow were recorded.

The exhaust system modifications included the assembly of a sleeve between the factory wideband oxygen sensor and its mounting socket in the exhaust pipe (figure 2). The sleeve enables the simulation of the outlet system leakage and allows the wideband oxygen sensor to work as it is offset from the main gasses stream while the system is sealed or leaking. The leakage is simulated with 4 bores evenly spaced around the sensor, measuring $3.5 \mathrm{~mm}$ in diameter each. The bores are made possibly close the oxygen sensors area, in which it collects the exhaust gasses from the pipe.

\section{RESEARCH}

The courses of torque, engine power and driving force generated by the tested engine are shown in figure 3 . The torque measured without modifying the exhaust system (curve 1) is the highest in comparison to the curves 2 and 3 in almost their whole length. This fact shows that both the installation of the sleeve and the leakage simulation lowered the utility parameters of the engine in a wide range of crankshaft rotation speed.
The shapes of curves 2 and 3 appear to be similar. Only between approximately 2800 RPM and 4000 RPM of crankshaft rotation speed during the exhaust system leakage simulation the torque was noticeably higher than during the measurements conducted when the system was sealed off. The mounting of the sleeve increased the distance between the area of wideband oxygen sensor, which is in contact with exhaust fumes flowing in the main stream inside the exhaust pipe. Additionally some sort of a bottleneck was created around the same part of the sensor. The electrical signal created by the wideband sensor is one of the most important in the process of computing the quality of the combustible mixture. It is possible that the sleeve distorted the flow of exhaust gasses near the oxygen sensor, thus influencing the readings on the sensor, so the composition of the air-fuel mixture changed and affected the torque.

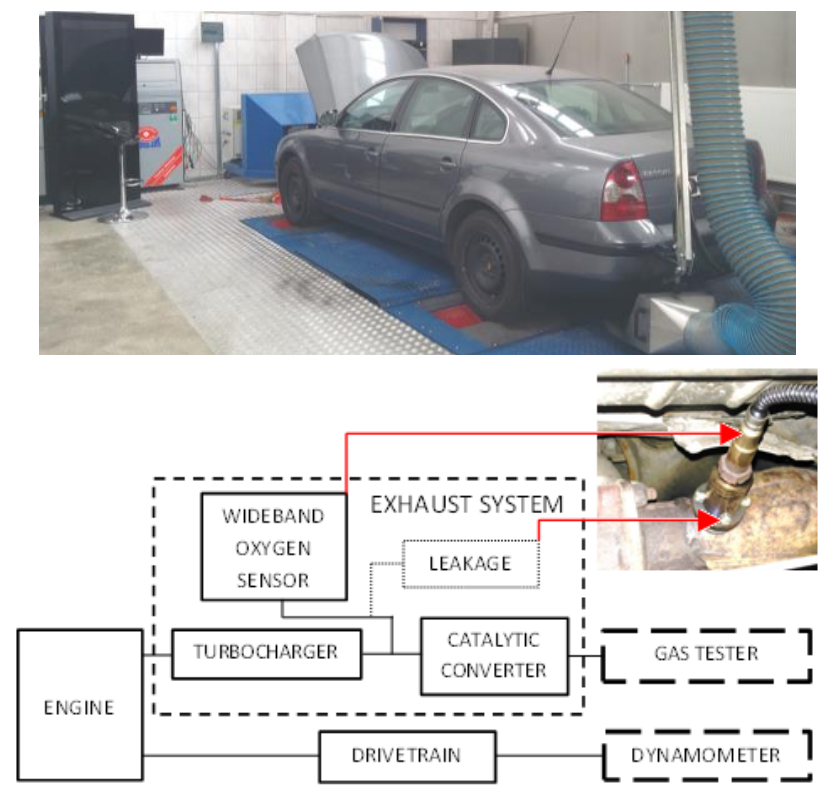

Fig. 2. On the top: the tested passenger vehicle mounted on the MAHA MSR 500 chassis dynamometer; on the bottom: the scheme of exhaust system leakage simulation measuring system

On the engine power courses there are no significant differences noticeable between the same measurement conditions. The power on the vehicles wheels equals the difference between the maximum power and power loss. The modifications tested in this research didn't affect the losses, so they were equal in each tested conditions.

The highest power courses were measured using the passenger car engine without modifications. From the start of the graph to about 2200 RPM the curves 2 and 3 are almost collinear with 1 . After this the curve 2, representing the test with the sleeve mounted and sealed, runs lower than the other two in the rest of the graph. Therefore it can be inferred that the installation of the sleeve between the exhaust pipe and the wideband oxygen sensor lowered the maximal power that the engine generated in each conditions and the leakage simulation partially recovers the torque course.

The charts presented in figure 4 allow for the air-fuel mixture composition analysis. As it is noticeable in the intake air mass flow graph, none of the modifications influenced the intake flow noticeably. The most important differences are visible in the injectors opening duration and wideband oxygen sensor voltage graphs. In the whole range of crankshaft rotation speed, the modifications caused the wideband sensor output voltage to be higher (or the Air-Fuel Ratio more rich) than under factory operating conditions. Higher 


\section{Eksploatacja i testy}

wideband sensor voltage affected the fuel injectors to remain open for a shorter time period and therefore dose lower volumes of fuel to the combustion chambers. In both graphs the courses no. 2 and 3 are very similar in their shape. It means that the sleeve installation and the simulated leak similarly influenced the research results.
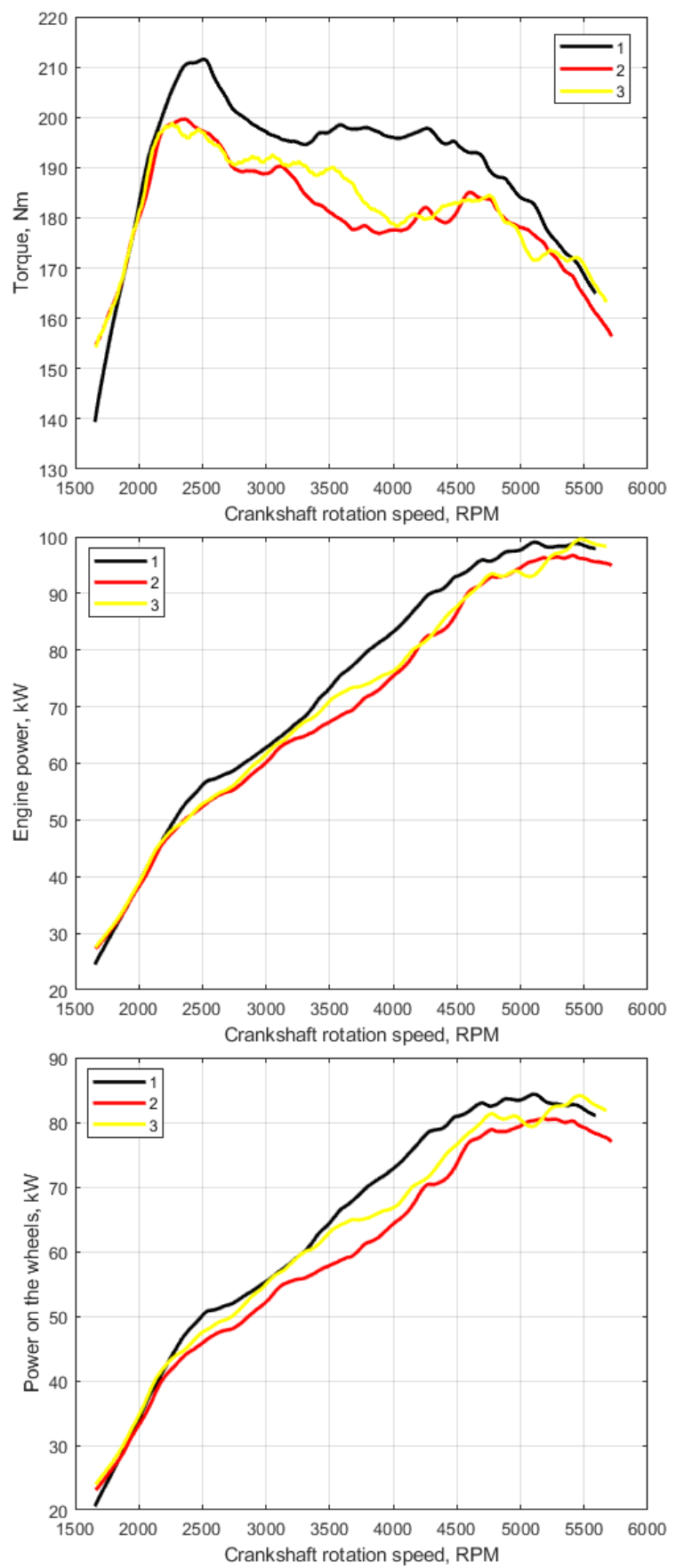

Fig. 3. Graphs of: on the top: measured torque courses; in the middle: engine power courses; on the bottom: power delivered to the wheels of the vehicle; 1 - factory configuration, 2 - with the sleeve mounted and the system sealed, 3 - leakage simulation

Narrowband oxygen sensor voltage, excessive air index $(\lambda)$ and oxygen concentration courses (the last two measured by the MAHA MGT 5 gas analyzer) are presented in figure 5 . The narrowband sensors are commonly used in turbocharged engines. They are mostly responsible for catalytic converter diagnostics, as they are mounted in the converter output. As the engine was working in its factory configuration the narrowband sensor output signal remained to be steady for the whole test time, about $0.8 \mathrm{~V}$. The results gath- ered for the other two configurations of the exhaust system are very similar to each other. In the first part they are decreasing from about $0.75 \mathrm{~V}$ to $0.7 \mathrm{~V}$. Then between $1800 \mathrm{RPM}$ and 2200 RPM of crankshaft rotation speed they are dropping to about $0.05 \mathrm{~V}$, remaining at this level to about 4800 RPM. In the last part of the test the signal voltage recovers to almost $0.8 \mathrm{~V}$. Such situation made a catalytic converter fault appear in the engine control unit (ECU) memory. The fault was deleted from the ECU after every test it appeared in.
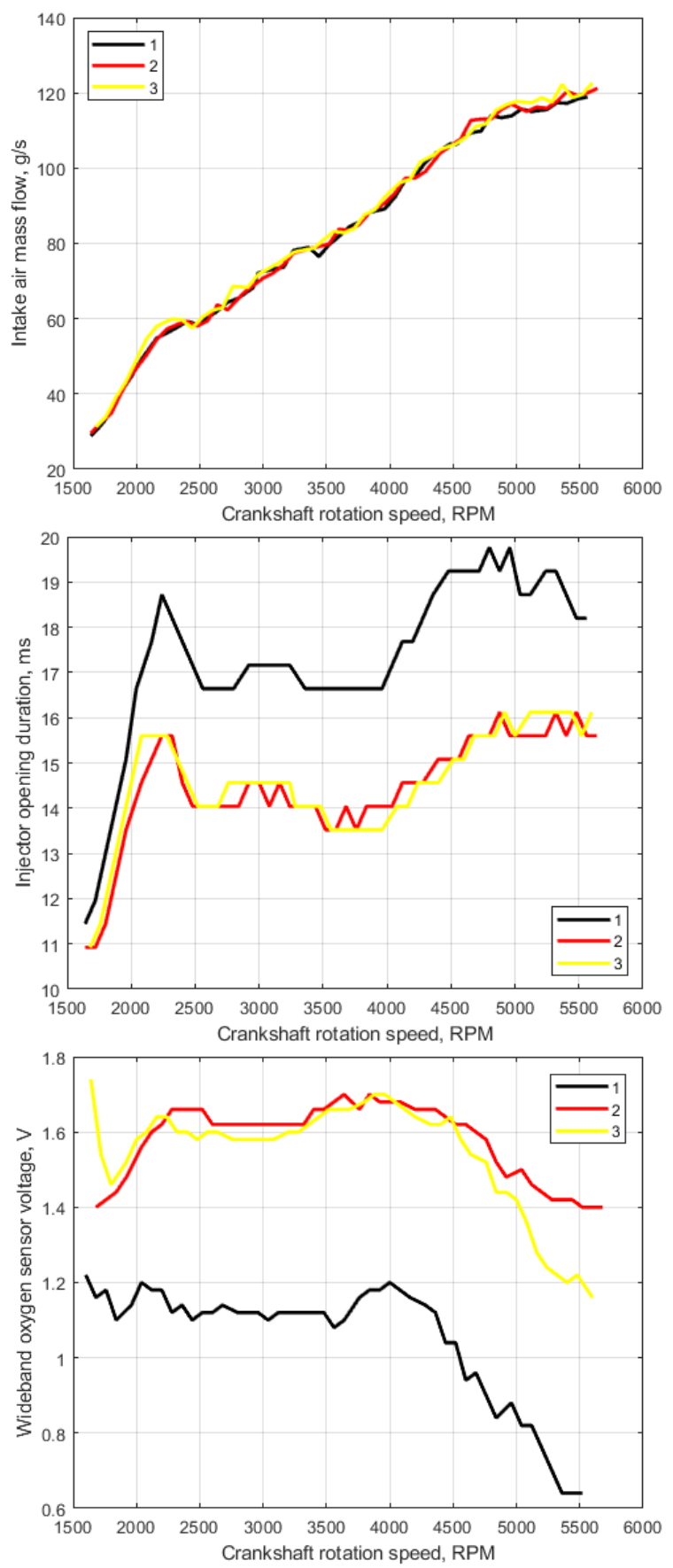

Fig. 4. On the top: measured intake air mass flows; in the middle: injector opening durations; on the bottom: wideband oxygen sensor voltage courses; 1 - factory configuration, 2 - with the sleeve mounted and the system sealed, 3 - leakage simulation

In the graphs of excessive air index and oxygen concentration in the exhaust gasses there are similar trends recognizable. The $\lambda$ courses start at values matching strongly lean air-fuel mixture and high $\mathrm{O} 2$ concentrations. According to figure 4, after about 2300 RPM the operating conditions of the engine stabilize however in the graphs it 
is visible a little bit later, because of the lag of the gas analyzer measurements. After the stabilization the average levels of curves 1,2 and 3 equal respectively about: 1.02 (slightly lean), 1.14 (clearly lean) and 1.17 (clearly lean). In the last part, after 5600 RPM the courses decrease respectively to: 0.97 (slightly rich), 1.09 and 1.11 . This could prove that both of the modifications gave a result of the combustible mixture to become leaner. At the same time the leakage simulation seems to give the results of the mixture to be leaner than while the engine was working with the sealed off sleeve.
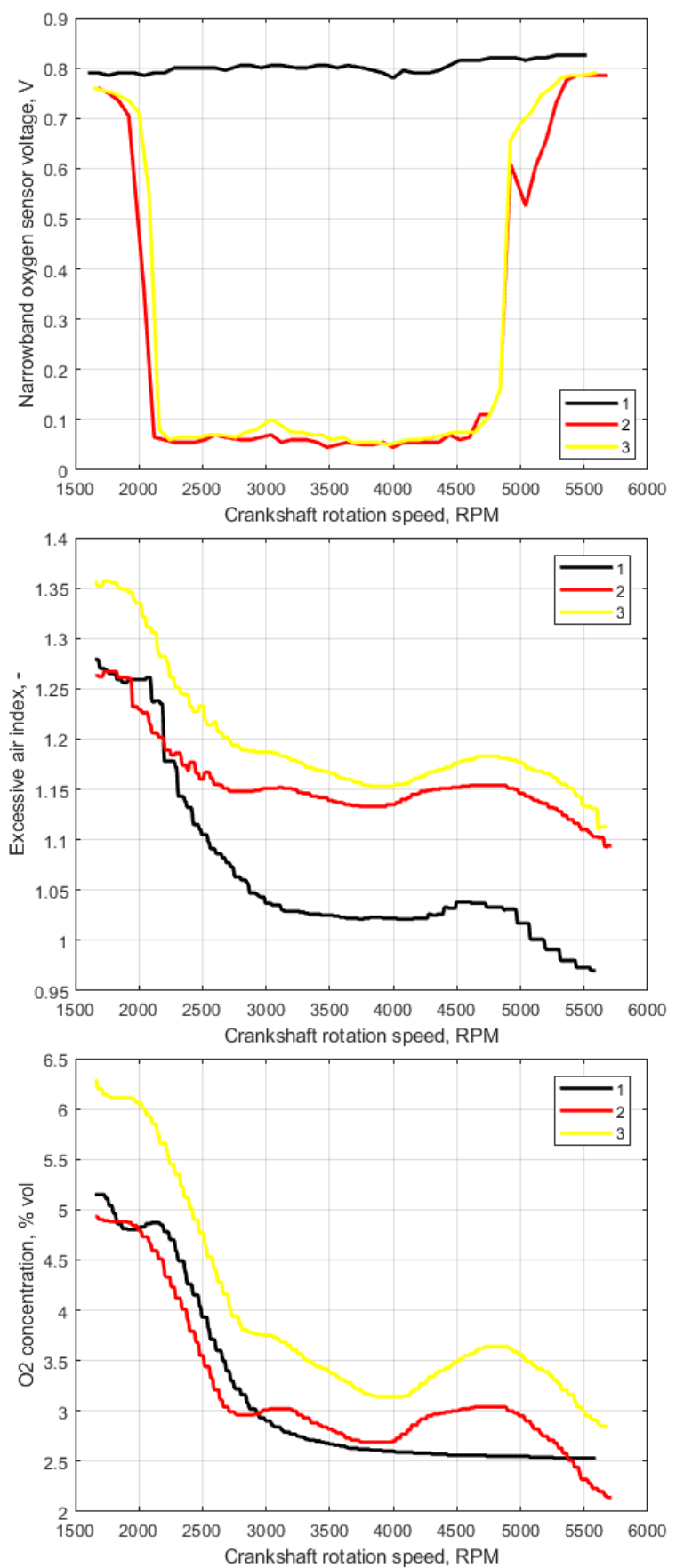

Fig. 5. On the top: narrowband oxygen sensor voltage courses; in the middle: excessive air index (data from the gas analyzer); on the bottom: oxide concentration; 1 - factory configuration, 2 - with the sleeve mounted and the system sealed, 3 -leakage simulation

The possible reasons are:

1. A certain volume of the exhaust gasses leaves the exhaust system through the bores in the sleeve, not being measured by the gas analyzer;
2. A certain volume of air is being sucked through the bores in the sleeve into the exhaust system, mixing with the fumes and falsifying the gas analyzer measurements;

3. The parameters of the combustible mixture changed according to the modifications or the catalytic converter fault appearing in the ECU.

4. A combination of above occurs.

The exhaust gas pressure in the area of the leakage simulation should be higher than the atmospheric one, because of the outflow coming from the piston movement and the flow resistance of the catalyzer (reason 1). However the flow of the gasses near the leakage could give an ejector effect, which might be the cause of air to be sucked into the exhaust pipe (reason 2). This air, mixed with exhaust gasses, resulted in a higher 02 concentration.
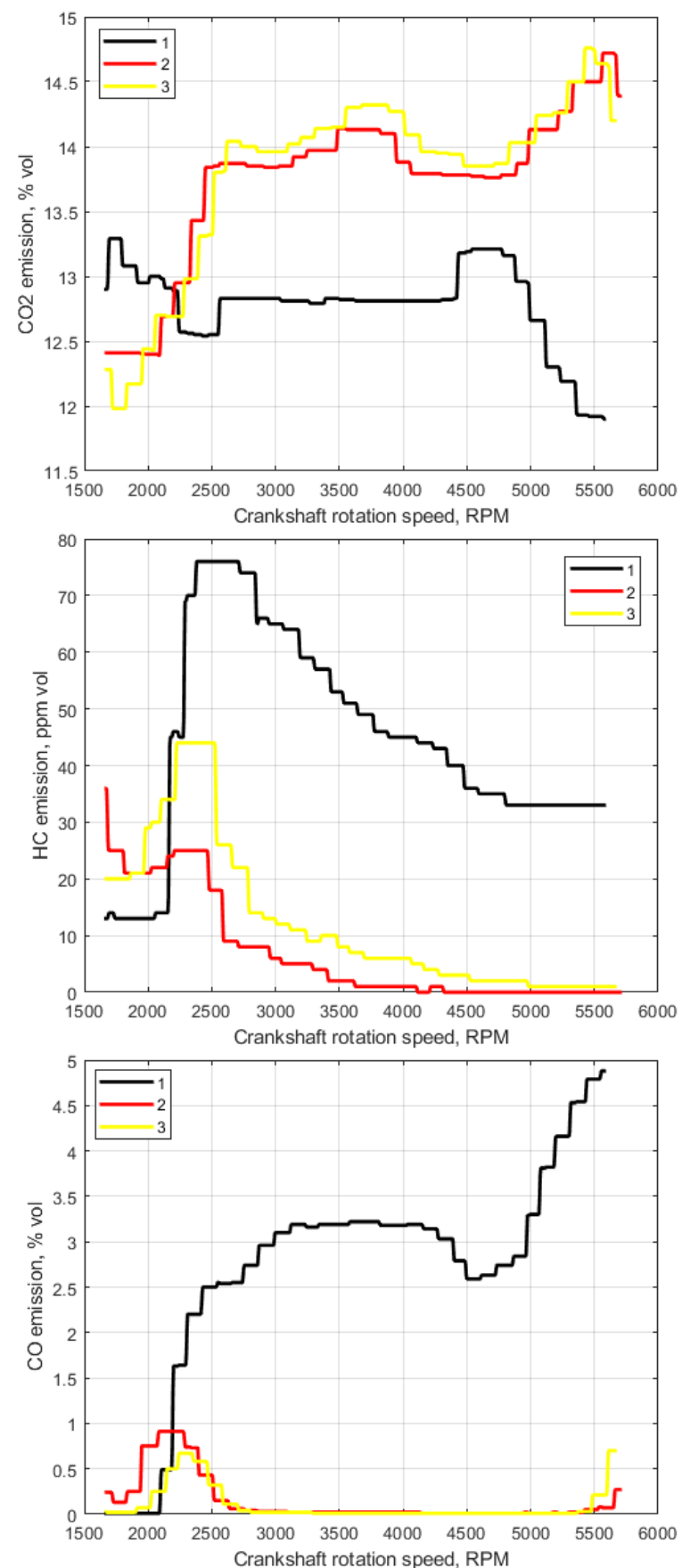

Fig. 6. On the top: carbon dioxide emissions; in the middle: hydrocarbon emissions; on the bottom: carbon monoxide emissions; 1 factory configuration, 2 - with the sleeve mounted and the system sealed, 3 - leakage simulation 
According to the data presented in figure 4 the fuel doses were lowered and the volume of intake air was comparable for each engine operating conditions, so a certain volume of oxygen might not get into the reaction with the fuel inside the combustion chamber. The lowering of the fuel doses by the ECU might be caused by the signal coming from the wideband oxygen sensor or from a catalytic converter fault. Therefore the possibilities no. 2 and 3 are the most reasonable.

In the $\mathrm{O} 2$ concentration graph, an increase of oxygen volume in exhaust fumes in leakage simulation in comparison with the other variants of engine operating conditions can be noted. According to figure 4 the parameters of the combustible mixture in sealed and leaking exhaust system conditions changed slightly, but to reach such a level of oxygen concentration increase, a certain amount of air had to be sucked inside the exhaust system.

The carbon dioxide, hydrocarbons and carbon monoxide emissions are presented in figure 6 . Comparing the factory operating and test-imposed conditions, the $\mathrm{CO} 2$ concentration has grown significantly. On the other hand, there was a great drop of both $\mathrm{HC}$ and $\mathrm{CO}$ emissions noticeable. As the air-fuel mixture became leaner, the injected amount of fuel had to be burned in an improved way, leaving smaller amounts of incomplete burning products. It is also possible that the operation of the catalytic converter was improved by higher oxygen concentration in the fumes, so the oxidation processes inside the converter occurred more effectively.

In lean burn conditions the emission of nitrous oxides should be higher than in normal conditions. This is mainly caused by the fact that lean air-fuel mixture results in higher combustion temperature which leads the formation of NO, NO2 and others. High combustion temperature can be a reason of major engine damage, for example a piston/head crack or melt. Lean mixture is also known to be more vulnerable to knock, also creating a risk of serious engine damage.

\section{CONCLUSION}

The modification of the exhaust system caused a series of differences that appeared both in the traction parameters of the passenger car engine and the toxic combustion product emissions. The offsetting of the wideband excessive oxygen sensor from the main fumes flow stream inside the exhaust line changed the parameters in a greater manner than the simulation of the leak. In general, the modifications significantly improved the emissions and fuel consumption while slightly lowering the power and torque of the engine.

It has to be kept in mind that during the engine operation in the leakage simulation a certain volume of air was sucked inside the exhaust system through the bores in the sleeve. This additional air could artificially improve the operation of the catalytic converter, falsifying the gas tester readouts. Considering the outflow velocity of the fumes, the wideband sensor had the access to the exhaust gasses whose chemical composition was not correspondent to the actual engine operating conditions. They were contaminated with fresh air from the engine compartment. In the conditions of the sealed sleeve, according to its shape, there was a risk that the exchange of the gasses near the sensing area of the wideband sensor will also be incorrect. This could cause the sensors momentary measurements to be inadequate to the engine operating conditions.

The influence of the alteration in the exhaust system on engine thermal load could also appear to be notable. Therefore the research should be extended with the measurement of the exhaust gas temperature in the area of the engine cylinder head's exhaust canals and NOx emissions.
Also the gas flow through the bores should be measured. This data could be used to prove the appearance of the ejector effect.

\section{REFERENCES}

1. MYSŁOWSKI J.: Pojazdy samochodowe. Doładowanie silników. Wydawnictwa Komunikacji i Łączności, wydanie 1, Warszawa 2002, ISBN-83-206-1445-7;

2. MAMALA J.: Kompensacja niedostatku siły napędowej w procesie rozpędzania samochodu osobowego, zeszyt 290, Oficyna Wydawnicza Politechniki Opolskiej, Opole 2011, ISSN 1429 6063 ;

3. KOŁODZIEJ S., GRABA M., BIENIEK A.: Ocena efektywności zasilania paliwem gazowym silników spalinowych. TTS Technika Transportu Szynowego, 12/2015, ISSN 1232-3829;

4. HENNEK K., KOŁODZIEJ S.: Wpływ profilu prędkości oraz ustawień regulatora położenia przepustnicy na zużycie paliwa w cyklach jezdnych. Autobusy. Technika, Eksploatacja, Systemy Transportowe, 6/2017, str. 729-732, ISSN 1509-5878, e-ISSN 2450-7725

5. BIENIEK A., GRABA M., HENNEK K., MAMALA J.: Analysis of fuel consumption of a spark ignition engine in the conditions of a variable load. MATEC Web of Conferences 118, 00036 (2017), DOI: $10.1051 /$ matecconf/201711800036

\section{Wpływ nieszczelności układu wylotowego spalin na parametry pracy turbodoładowanego silnika o zapłonie iskrowym}

Układy turbodoładowania sq obecnie najczęściej stosowanymi układami zwiększającymi moc silników spalinowych. Obecnie nietrudno spotkać na drodze pojazdy wyposażone $w$ tego typu silniki ze znacznym przebiegiem, a co za tym idzie z podwyższonym ryzykiem wystapienia nieszczelności w układach wylotowych spalin, majacych wplyw nie tylko na powstajaca emisję, ale równiez na parametry pracy tych silników. Stąd w pracy przedstawiono analizę porównawcza wpływu nieszczelności układu wylotowego na skład spalin na wyjściu z katalizatora oraz parametrów pracy turbodoładowanego silnika ZI. Podczas badań rejestrowano takie parametry jego pracy jak: moment obrotowy, czas otwarcia wtryskiwaczy, sygnaty napięciowe sond lambda na wejściu $i$ wyjściu katalizatora oraz stężenie substancji szkodliwych $w$ spalinach. Badania przeprowadzono na jednorolkowej hamowni podwoziowej MAHA MSR 500, na której wykonano szereg pomiarów mocy silnika testowanego pojazdu. W ramach tych pomiarów dokonywano symulacji nieszczelności układu wydechowego turbodoładowanego silnika, w wyniku których uzyskano trzy warianty działania szerokopasmowej sondy lambda, zamontowanej pomiędzy zespolem turbospręzarki a katalizatorem spalin.

Autorzy:

mgr inż. Krystian HENNEK - Politechnika Opolska, Wydział Mechaniczny, Katedra Pojazdów, e-mail: k.hennek@po.opole.pl

dr inż. Mariusz GRABA - Politechnika Opolska, Wydział Mechaniczny, Katedra Pojazdów, e-mail: m.graba@po.opole.pl

JEL: L62 DOI: 10.24136/atest.2018.114

Data zgłoszenia: 2018.05.23 Data akceptacji: 2018.06.15 